\title{
О.И. Недоступ
}

Новосибирский государственный педагогический университет

\section{Тождественные синонимы в словаре и тексте}

Аннотация: В статье на примере синонимической пары осьминог - cnрут показан механизм анализа системных и функциональных свойств единиц, относимых лингвистами к абсолютным синонимам, что отражает доминантные положения диссертационной работы - об относительности понятия «абсолютные синонимы» и постоянно идущем процессе сокращения их объема в современном русском языке.

The analysis mechanism of system and functional properties of units, classified by linguists to absolute synonyms, is represented in the article in example of the synonymous pair octopus - 'sprut'. It reflects the dominant positions about relativity of «absolute synonyms» notion and constant process of their reduction in the modern Russian language.

Ключевые слова: абсолютные / точные синонимы, лексикографический и контекстный аспекты значений синонимов, степень семантической дискретности; синонимия и многозначность.

Absolute / exact synonyms, dictionary and contextual aspects of synonyms semantic values, the degree of semantic discretion; synonymy and polysemy.

УДК: 81 '373.421.

Контактная информация: Новосибирск, ул. Вилюйская, 28. НГПУ. Тел. (383) 2440126. E-mail: ole8880836@yandex.ru.

Вопрос о тождестве или не тождестве значений так называемых абсолютных синонимов обусловливает постановку проблемы степени дискретности их значений. Считается, что для содержания точных синонимов характерен одинаковый семный состав. По определению Ю.Д. Апресяна, «если толкования двух слов полностью совпадают, то они являются точными по семантике» [Апресян, 1995, c. 213]. Однако, как правило, в значениях многих слов, относимых лексикологами к абсолютным синонимам, можно наблюдать несовпадения, то есть толкование одного синонима не совпадает с дефиницией другого. А в разных словарях степень полноты семного состава синонимических значений не совпадает, что связано с лексикографической лакунарностью.

Проблема дискретирования семантики лексических единиц всегда так или иначе отражалась в работах лингвистов, однако именно в настоящее время интерес к ней возрос. Как замечает А.Я. Шайкевич, «становление семантических дискретностей - интересный возможный объект лингвистических изысканий, пока совершенно не изученный и не имеющий адекватного исследовательского инструментария» [Шайкевич, 1996, с. 45]. Мы считаем, что это несколько преувеличено, так как в последние десятилетия при помощи метода компонентного анализа и его «помощников» (дефиниционного и контекстного анализа, метода ассоциативного эксперимента) получены значительные результаты в изучении членимости словесной семантики [Евгеньева, 1970; Стернин, 1985; Михайлова, 1999; Грязнова, 2006; Должикова, 2006; Трипольская, 2009]. 
Некоторые исследователи [Шмелев, 1977; Апресян, 1995] считали надуманным полагать, что большинство лексических единиц способны к активному дискретированию. Так, Ю.Д. Апресян в начале 70-х годов XX века писал, что «меру дискретности значений при их описании в толковом словаре сильно преувеличивают и видят четкие границы там, где фактически, при ориентации на реальное разнообразие текстов, обнаруживается реальная промежуточная область» [Апресян, 1971, с. 172]. Впоследствии, под влиянием антропоцентрических исследований языка, идея дискретности значений получила особо значимый статус в лингвистике.

Вслед за О.А. Михайловой, мы считаем, что «дискретность является одним из обязательных свойств языкового значения, определяющих системный характер языка» [Михайлова, 1999, с. 70]. В данном случае можно говорить о том, что значения внутри семантической структуры слова являются выделимыми, и каждое из них может вводить слово в разные системные парадигмы; само значение состоит из выделимых частей (сем), которые могут быть основой ЛСГ, синонимических рядов. О дискретности как «выделимости» говорит и С.Н. Должикова: дискретностью является «выделимость объекта из множества однородных с ним предметов, существование его как отдельной субстанции» [Должикова, 2006, с. 75].

Остановимся на паре синонимов: осьминог, спрут, которые успешно поддаются дискретизации, их лексикографический и контекстный анализ может стать прецедентным для выявления тенденций существования абсолютных синонимов в современном русском языке.

Обратимся к словарным толкованиям указанных единиц. Словарная семантика номинации осьминог - «морское животное из рода головоногих моллюсков с мешкообразным телом и восемью щупальцами с присосками; спрут» [Ожегов, Шведова, 2004, с. 410]. Дефиниция синонима спрут - «обиходное название крупного осьминога, а также гигантского кальмара» [Там же, с. 675].

Первая дефиниция - детальная, что можно объяснить сложной основой термина, она включает такие семантические компоненты, как 'разновидность моллюсков', 'морское животное', 'мешкообразное тело', 'восемь щупальцев'. Необходимо заметить, что слово спрут заимствовано из английского языка (sprat килька, шпрот). Обращаясь к значениям слов килька и шпрот («мелкая промысловая рыба»), мы вычленяем дифференциальную сему 'малый размер'. Данная сема не актуальна для носителей русского языка по отношению к слову спрут, однако для более полной характеристики системного значения этой единицы является значимой, так как дает дополнительное основание для дифференциации значений указанных слов.

Вторая дефиниция - отсылочная, а поэтому сама по себе малоинформативная, за исключением семы 'большой размер' и семы, связанной со сферой употребления слова («обиходное»). Это позволяет отнести рассматриваемые синонимы к семантико-стилистическим, в то время как отсылочное толкование частично отождествляет эти слова, но вводит еще один образ - 'кальмар'. Большой словарь иностранных слов (далее - БСИС) дает следующую дефиницию слова кальмар «подотряд морских головоногих моллюсков отряда десятиногих; некоторые виды являются самыми крупными беспозвоночными животными, достигающими 18 метров» [БСИС, 2006, с. 327]. В свою очередь, семантический компонент 'кальмар' в рамках дефиниции синонима спрут эксплицирует две основные дифференциальные семы: 'десять щупальцев' и 'размер до 18 метров', - которые не заложены в содержании слова осьминог. Таким образом, понятие «спрут» более широкое, чем понятие «осьминог». Дефиниция слова спрут свидетельствует о том, что данная лексема в русском языке является родовым названием для номинаций осьминог и кальмар. Уже этот факт говорит о том, что осьминог и cпрут - не абсолютные синонимы. 
Не вызывает сомнения тот факт, что основные семантические компоненты значения слова наиболее полно представлены в толковых словарях. Однако для более объективного описания значений синонимов осьминог - спрут следует учесть данные и синонимических словарей, которые, в первую очередь, устанавливают не только сходство между описываемыми синонимическими единицами, но и существенные различия их значений. Обратимся к толкованиям лексем осьминог - спрут, репрезентируемых Словарем синонимов русского языка под редакцией А.П. Евгеньевой (далее- ССРЯ). Осьминог - «морское животное рода головоногих моллюсков, с мешкообразным телом и восемью щупальцами, служащими орудием нападения и защиты; спрут» [ССРЯ, 1987, с. 81]. Слово спрут толкуется в данном словаре как «обиходное название крупного осьминога; спрут» [Там же, с. 127]. В словаре синонимов (в отличие от толкового словаря) в значении слова осьминог актуализируются семы «нападение» и «защита». Семантический объем синонима спрут, как видно из дефиниции, существенно сужен, по сравнению с его представленностью в толковом словаре.

Таким образом, в словарных дефинициях изучаемых синонимов мы наблюдаем разные способы отражения дискретности их значений. Лексикографические данные всегда можно дополнить исследованием контекстуального «поведения» синонимов.

Обратимся к особенностям употребления рассматриваемых синонимов, приведя соответствующие контексты.

В верхней части «башни» $\kappa$ скале прилепился крупный осьминог (А. Городецкий). Здесь словоформа осьминог актуализирует сему 'крупный размер', что соответствует толкованию номинации спрут («крупный осьминог»). Можно сказать: $K$ верхней части «башни» прилепился спрут. Это случай контекстуальной, ситуативной тождественности синонимов, когда в определенный контекстных условиях синонимы способны к полной взаимозамене, хотя словообразовательная внутренняя форма номинации осьминог в большей мере обусловливает семантическое согласование данного слова с глаголом прилепиться (...c восемью щупальцами-присосками).

Слово осьминог функционирует в контекстах, уточняющих его предметновещественную семантику: Второе: я ждал, что о стекло рубки хряпнется кальмар или осьминог, чего не случилось (Э. Лимонов. Книга воды). Здесь мы наблюдаем (и об этом свидетельствует именно разделительный, а не пояснительный союз ИЛИ), что осьминог и кальмар - разные морские существа, представления о которые объединяются понятием спрут. Лакунарность словарной дефиниции осьминог (когда это животное приравнивается к спруту) - налицо.

В следующем контексте данное различие не актуализируется: В основном добывается то, что не пользуется спросом в России: морской еж, осьминог пояснил «Известиям» независимый эксперт международного морского права профессор Константин Горенский (Нильс Иогансен. Клева! Японцы покушаются на российскую рыбу).

По нашим наблюдениям, номинация спрут, на основе ассоциативной связи, способна развивать вторичные значения (чему способствует и ее обобщенное содержание), не отмеченные словарями. Тем самым слово спрут еще больше в смысловом отношении отделяется от слова осьминог. Приведем примеры.

Сегодня у «Сатурн-Р» есть традиционные партнеры, совместно с которыми построен не один объект и на каждом установлены системы пожаротушения, над монтажом которых всегда трудились специиалисты фирмы «Спрут-НП» (И. Логинова. Мы строим). Переносное метафорическое значение лексемы спрут эксплицирует наименование организации; происходит и лексикограмматическое преобразование слова: нарицательное имя переходит в собственное. И аналогичных контекстов с техническим, специализированным содержанием немало, однако они редко информируют мотивировку указанного метафориче- 
ского переноса. Например: Для скважинь диаметром 245 мм полиэтиленовый рукав должен быть иириной 310 - 315 мм и насажен на систему "Спрут» при его длине на 1,5 - 2 м большей, чем глубина заряженной скважины (Совершенствование буровзрывчатых работ на Донском ГОКе). В основе данной номинации системы лежит ассоциативный образ морского существа, ранее описанного нами при помощи толкового словаря. Но об этом можно только догадываться, так как сам контекст не «поддерживает» переносное значение, за исключением, может быть, слабого намека при помощи словоформы «на систему» (поведение большого морского существа, все многочисленные щупальца которого работают слаженно, напоминает сложный механизм, систему).

На основе сходства по функции при метафорическом переосмыслении может проявиться контекстно «поддержанная» смысловая модификация лексемы спрут: Наилучшие результаты дает использование клея "Спрут» (К. Скворцов. Из банки от сока). Контекст показывает: клей прочно склеивает, как спрут, опутывает своими щупальцами. В данном случае также можно говорить и о лексикограмматической модификации - переходе нарицательного имени в собственное название торговой марки.

Метафоризованное значение спрут может и не иметь лексикограмматического преобразования, соединяясь с эмотивной оценкой метафоризованным глаголом опутал: Как известно, нам предстояла борьба с московской корпораџией МИКОМ, подмявшей под себя КМК, ПкАЗ. Микомовский спрут опутал половину Кузбасса (Лидер экономики рынка).

Слово осьминог может проявлять метонимическое значение, функционируя как номинант блюда:

Осьминог, спасаясь, выпускает чернила. Его все же ловят и едят: любимое блюдо испанцев «осьминог в своих чернилах» (А. Крищенко. Небылицы о том, кто был).

Таким образом, можно говорить не только о степени семантической дискретности рассматриваемых синонимов, но и о степени континуальности их контекстного окружения: оно по-разному диагностирует особенности семантической модификации изучаемых единиц.

Подведем итоги. Семантическая дискретность словарных дефиниций синонимов осьминог - спрут представлена достаточно ощутимо, но в толкованиях данных слов имеют место несовпадения. Например, в словарях нечетко выражены родо-видовые отношения между словами спрут, кальмар и осьминог, что обусловлено особенностями репрезентирования информации о синонимах в толковых и синонимических словарях. Анализ словарных толкований в соединении с описанием дистрибутивной специфики рассматриваемых единиц (с учетом степени диагностичности контекста) позволяет не считать их в полной мере абсолютными синонимами. Об этом свидетельствует и развитие семантических модификаций анализируемых единиц, например, проявление переносных значений, которые не отмечены словарями: слово спрут развивает метафорические значения, а осьминог - метонимическое. Это ограничивает возможность их взаимозаменяемости.

Предложенную в данной статье методику анализа можно применить ко многим так называемым абсолютным синонимам с целью уточнения их статуса.

\section{Литература}

Апресян Ю.Д. Лексическая семантика. Синонимические средства языка. M., 1995

Большой словарь иностранных слов. М., 2006.

Должикова С.Н. Средства национально-культурной номинации: содержательный аспект // Вторые Международные Бодуэновские чтения: И.А. Бодуэн де 
Куртене и современные проблемы теоретического и прикладного языкознания. Казань, 2006.

Михайлова О.А. Лексическое значение в свете альтернативных парадигм // Известия Уральского государственного университета. Екатеринбург, 1999. Вып. 2.

Ожегов С.И., Шведова Н.Ю. Толковый словарь русского языка. М., 2004.

Словарь синонимов русского языка / Гл. ред. А.П. Евгеньева. М., 1987.

Шайкевич А.Я. Оковы слова (или поиски семантической дискретности). М., 1996. 